\title{
KRONIK
}

\section{Arbejdet som middel, mennesket som mål - eller omvendt?}

Mikkel B.B. Morgen

Det er et efterhånden velkendt fænomen, at dansk arbejdsmarkedspolitik siden midten af 1990'erne har båret præg af en bred og stigende favorisering af en såkaldt 'aktiv' linje. Her bevæger man sig bort fra tidligere tiders mere eller mindre passive forsørgelse af arbejdsløse henimod strengere krav om aktivering i beskæftigelsesindsatser, større kontrol med borgere på forsørgelse og fokus på borgerens pligt til gennem lønnet beskæftigelse at bidrage til velfærdssamfundets sammenhængskraft (Bredgaard, Jørgensen, Madsen \& Rasmussen, 2011; Goli, 2016). I årene omkring førtidspensions- og fleksjobreformen af 2013 så denne udvikling imidlertid ud til at træde ind i et nyt stadie i kraft af, at daværende beskæftigelsesminister i den socialdemokratiske regering, Mette Frederiksen, fremførte behovet for en stærkt intensiveret beskæftigelsesorientering af den danske socialpolitik. Frederiksens diagnosticering af socialpolitikken lød på dette tidspunkt, at man på trods af en allerede stigende tendens til samkøring af arbejdsmarkeds- og socialpolitik havde svigtet eller opgivet disse mennesker, ved ikke at have stillet større krav om selvforsørgelse. Men ikke længere. Socialpolitikken måtte i endnu højere grad end hidtil rettes imod opnåelse af erhvervsarbejde til langt flere danskere med vanskelige sociale livsvilkår, og kravene blev opført i den gode og solidariske sags tjeneste: At vi alle må bidrage med det, som vi kan, såfremt vi skal kunne opretholde et fælles velfærdssamfund. Det var dog ikke kun pligten, som var bærende for de nye formuleringer af en socialpolitik med beskæftigelse for øje:

\section{"(...) jeg tror på vigtigheden af, at man som menneske kan gøre nytte. At det er bedre at have noget at stå op til end det modsatte. Jeg er så gammeldags. Og jeg er så meget social- demokrat, at jeg grundloeggende tror på, at det er bedst, når voksne mennesker går på arbejde." (Frederiksen, 2013)}

Frederiksens udtalelser lå på daværende tidspunkt ukontroversielt på linje med de dele af sundhedsforskningen, der gør sig til fortaler for lønarbejde som et essentielt, universelt sundhedsfremmende element $i$ et menneskeliv og virkede som en afgørende 'rød blåstempling' af det sidste årtis overvejende borgerlige udvikling af en aktiv beskæftigelsespolitik. Lønarbejdet - som jeg her adskiller fra øvrige typer af skabende og omdannende menneskelige aktivitetsformer - blev med førtidspensionsreformen af 2013 indsat som et helt centralt middel til både 
et bæredygtigt velfærdssamfund men også til udvikling af det gode og værdige menneskeliv. Dvs. en på overfladen humanistisk og nærmest kantiansk formulering af lønarbejdet som middel, mennesket som mål. Det store og helt centrale spørgsmål her seks år senere må være: Er lønarbejdet blevet det middel til et bedre liv for udsatte borgere, som man har håbet på fra politisk hold? Har beskæftigelsesorienteringen vist sig at være svaret på socialpolitikkens udfordringer?

\section{Farvede kugler og plexi-rør}

Meget tyder på, at svaret på ovenstående falder til den negative side i form af et 'nej'. Bruttoledigheden er faldet til sit laveste punkt siden 2009 (Eeg \& Jensen, 2018), hvorfor det vel med rimelighed kan siges, at det sidste årtis beskæftigelsespolitik har opfyldt dens formål - såfremt man altså godtager, at beskæftigelsespolitikkens opgave udelukkende er af kvantitativ art og udgjort af et snævert fokus på lavest mulig statistisk ledighedsgrad blandt befolkningen. Anskuer man imidlertid mere socialpolitiske indikatorer så som hjemløshed, antal borgere uden registreret forsørgelsesgrundlag, ulighed i materielle levevilkår og fattigdom, tegnes der et væsentligt andet billede (Benjaminsen, 2017; Caspersen, 2018; Juul, 2018). Et billede hvori sociale udfordringer fremstår forværret parallelt med det stærkt forøgede fokus på at få udsatte borgere i lønnet beskæftigelse som et socialpolitisk værktøj. Foruden de statistiske opmålinger kan man i den offentlige samtale registrere, hvad der kunne benævnes som en intensiveret social uro. Uroen kommer til udtryk gennem et forsøg på øget kollektiv mobilisering blandt arbejdsløse og syge, hvilket primært finder sted over sociale medier grundet naturligt begrænsede fysiske, materielle og mentale ressourcer blandt denne gruppe mennesker. Mobiliseringen er et særsyn, idet særligt længerevarende arbejdsløshed historisk set har været koblet til en helt grundlæggende socialpsykologisk udvikling af håbløshed, selvhad, apati og inderliggørelse af samfundets latente kritik af den arbejdsløse (Jahoda, 1982). Samtidig kan man identificere en øget kritisk diskursivering af vilkårene for beskæftigelsesindsatsen fra Dansk Socialrådgiverforenings side såvel som fra enkeltstående socialrådgivere, der tager bladet fra munden og taler ud om arbejdsforhold, der i allerhøjeste grad risikerer at føre til behandlingen af udsatte borgere som blot endnu et sagsnummer i rækken. Altså, at socialrådgiveren i ordets strengeste forstand og reelt i praksis reduceres til sagsbehandler, sådan som jobbetegnelsen for socialrådgivere i beskæftigelsesfeltet da også oftest officielt lyder i stillingsopslag.

At beskæftigelsesfeltet ikke er tilstrækkelig omstillet til at kunne rumme arbejdet med socialpolitikkens genstandsfelt (i form af socialt udsatte borgere) kan blandt andet ses i relation til den stramme økonomiske rationalitetsform, der er styrende for beskæftigelsessystemet, og som sætter sig i gennem på alle praksisniveauer fra nationalpolitisk niveau, til kommunalpolitik, til jobcenterledelsen, til sagsbehandler. Kritikken må derfor ikke lyde som en udpegning af 'de inkompetente praktikere' eller 'de onde økonomifetichistiske ledere'. Der er mere på spil end som så, og de neoliberale styringsteknologier ser i nogen tilfælde ud til at få deres eget liv i kraft af en løbende naturalisering af den økonomiske instrumentalisering af mennesket, som vi i fællesskab har ladet hænde. Et mikro-eksempel på, hvordan økonomifikserede styringsteknologier rammesætter det praktiske arbejde med socialt udsatte i beskæftigelsesfeltet er 'plexiglas-rørene'. Dem er jeg stødt på i min forhenværende stilling som arbejdspædagogisk konsulent, og de ses til offentlige skue på et - her anonymiseret - jobcenters hovedgang. Der er fire af dem. Ét rør for hver afdeling med 
hver sin borgermålgruppe: Sygedagpenge, kontanthjælp, ressourceforløb og jobafklaringsydelse. Hvert af de vertikalt stående plexiglas-rør er mere eller mindre fyldt med plastikbolde i forskellige farver, og ovenover hænger en guide til fortolkning af kuglernes farver. Guiden lader forstå, at en kugle repræsenterer en afsluttet borger (eller borger som er overgået til anden offentlig instans i det mindste), og at de forskellige farver symboliserer intervaller ift. det antal ordinære løntimer, som man har opnået med den enkelte borger. Måske på overfladen en uskyldig og harmløs intern konkurrence mellem afdelingerne om at få fyldt sit plexi-rør hurtigst, men samtidig en meget klar statuering af det kvantitative lønarbejde-outcome som det primære succeskriterie fremfor borgerens erfaring af processen, arbejdet, dennes læring eller livskvalitet. Ikke bedring af sociale livsvilkår. Timeantallet er det væsentligste i denne konkurrencekonstruktion, hvilket jeg vil mene er et generalisérbart fænomen inden for beskæftigelsesfeltet. I lyset heraf, skulle man så retfærdigvis kunne mene, at beskæftigelsessystemet er gearet til at skulle fungere som svaret på socialpolitikkens opgaver? At beskæftigelsesfeltet i det hele taget har udvist vilje eller mulighed for at tilegne sig denne selvforståelse som løsningen på socialpolitiske udfordringer? Det snævre fokus på antal opnåede løntimer ville fremtone mindre problematisk, såfremt beskæftigelsesfeltet blot havde til formål at formidle arbejde til den gruppe af mennesker, der er 'tæt på arbejdsmarkedet' og ofte kun er arbejdsløse i kortere tid, men har man som formål, at beskæftigelse skal være et redskab i arbejdet med socialt udsatte borgere, så præsenterer denne snævre fokusering en væsentlig problemstilling.

Hvad angår instrumentaliseringen af det enkelte menneske, bør man formentlig være påpasselig med at undervurdere de praktiske og relationelle effekter heraf. Dvs. at undervurdere præcist i hvor markant grad den enkelte borger subjektivt erfarer denne instrumentalisering, om end den kan komme i en indpakning af gode intentioner. Eksempelvis er der i det store forskningsbaserede BeskæftigelsesIndikatorProjekt i det seneste år blevet fremhævet, hvordan sagsbehandlerens tro på borgerens muligheder for at komme tilbage i lønarbejde øger den statistiske sandsynlighed for dette (Rosholm, Sørensen \& Skipper, 2017). Imidlertid kan der efter denne videnskabelige erkendelse spores tendenser i retning af en instrumentalisering af denne 'tiltro' i beskæftigelsespraksis. Altså at tiltroen kan bruges som et påtaget teknisk-pædagogisk værktøj over for den enkelte borger. Oversættelsen fra forskning til praksis kan vise sig problematisk, da det hænder, at nogle sagsbehandlere ud af gode intentioner får udøvet en art insisterende positiv psykologi eller 'appreciative inquiry'. Det vil sige, at man i samtaler med borgere ubevidst kommer til at underkende eller negligere borgerens negative erfaringer og italesættelser af bekymringer samt udfordringer - ud fra en tanke om, at man må fokusere samtalen på det, der allerede går godt, på ressourcerne og på håbet $\mathrm{om}$, at lønarbejde kan blive en mulighed igen. Og så i øvrigt ikke rode for meget rundt i alt det negative. Imidlertid har jeg oplevet, at denne tilgang risikerer at få en modsat effekt, såfremt borgeren afkoder en instrumentel rationalitet som liggende bagved denne tiltro, hvilket fører til et begrænset engagement $\mathrm{i}$ relationen til sagsbehandleren og reduceret fortællelyst om egne erfaringer og situation. Altså en decideret indesluttethed. Noget der næppe kan siges at danne grobund for produktive læreprocesser og socialfagligt/ pædagogisk arbejde. 


\section{"Noget (lønarbejde) at stå op til."}

Som beskrevet i indledningen, så er den umiddelbare intention, der synes at ligge til grund for den daværende socialdemokratiske regerings videreførte 'beskæftigelseskolonisering' af socialpolitikken, ikke nødvendigvis dårlig eller uværdig i sig selv: Altså groft sagt 'mennesket som mål, arbejdet som middel'. Nej, intentionen kan synes at have været god. Dog fremkommer det blandt andet i en nylig debat på DR (Danmark for de udsatte?) - hvor Socialdemokratiets børne- og socialordfører, Pernille Rosenkrantz-Theil, udtrykker en oplevelse af, at førtidspensionsreformen fra 2013 er blevet læst af mange kommuner, som fanden læser biblen - at intentionerne bag reformen ikke var blevet virkeliggjort. Med andre ord, at beskæftigelsesfokuseringen og øgede krav til deltagelse i lønarbejde blandt udsatte borgere ikke havde ledt til bedre løsning af de sociale udfordringer. Måske, og som allerede antydet tidligere, snarere tværtimod. Og hvad kan det så skyldes?

Pernille Rosenkrantz-Theils eget bud er, at biblen - læs; reformens lovgivning - ikke er skrevet godt nok, og at dette baner vej for fandens frie læsning af den. Og gad vide om ikke fandens læsning bliver muliggjort og fremkaldt som resultat af økonomiske styringsteknologier og den øgede drift af offentlige institutioner såsom jobcentrene ud fra markedsvilkår, der medfører, at borgeren ender som den førnævnte farvede kugle i et plexiglas-rør. At mennesket bliver midlet til et samfundsmæssigt mål om højest mulig beskæftigelsesgrad, bedst mulig budgetoverholdelse og dermed samfundsøkonomisk vækst og velstand. Rosenkrantz-Theils bud var, at de juridisk-tekniske formuleringer i lovgivningen ikke er stramme eller skarpe nok og dermed danner kimen til en forråelse i praktiseringen af lovgivningen. Jeg vil dog mene, at der i udviklingen af den 'aktive' beskæftigelsespolitik og den 'beskæftigelsesrettede' socialpolitik, er yderligere et væsentligt problem at spore: at man ikke har udvist tilstrækkelig refleksion over arbejdets potentielle mangfoldighed og ikke har formået at indholdsbestemme, hvad det er for typer arbejde, der skal kunne bidrage til løsning af sociale udfordringer i samfundet og for den enkelte borger. Det kommer i stedet til at forholde sig således, at arbejde er lig med lønarbejde, at lønarbejde er lønarbejde og at lønarbejde er sundt.

I det indledende citat fra Mette Frederiksens tale til Foreningen af Kommunale Social-, Sundheds- og Arbejdsmarkedschefer begrundes indførslen af et strammere beskæftigelsesperspektiv i socialpolitikken, at det er bedre at have noget at stå op til end det modsatte. Altså, der fremsættes en påstand om, at lønarbejde universelt set er sund og godt. Med denne påstand følger en ualmindeligt (eller skulle man desværre efterhånden sige 'almindeligt') indskrænket forestillingsevne, hvad angår anlægget for at begribe, hvordan et menneskeliv kunne indeholde andet at stå op for end det ordinære lønarbejde. Nok taler Frederiksens påstand sig som sagt på fin vis ind i megen af den sundhedsfremmeforskning, der peger på, hvordan arbejdsløshed har forbindelse til nedsat mentalt og fysisk helbred (ex. Goodman, 2015; Ross \& Mirowsky, 1995; Turner $\&$ Turner, 2004). Om forbindelsen er præget af kausalitet eller korrelation er imidlertid gådefuldt i denne forskning: nedsættes helbredet som følge af arbejdsløshed, eller er man arbejdsløs som følge af helbredet? Formentlig går det begge veje, men selv i det sandsynlige og generelt velpåviste tilfælde, at helbredet nedsættes som følge af arbejdsløshed, så ved man reelt set ikke, om denne reduktion skyldes det funktionelle fravær af lønarbejdsaktivitet i sig selv - eller om det i lige så høj grad skyldes måderne, hvorpå 
organiseringen af vores beskæftigelsessystem har indvirkning på det enkelte menneskes muligheder for daglig livsførelse og erfaringsdannelse i forbindelse med perioder af arbejdsløshed. Det vil sige: bliver arbejdsløshed et helbredsmæssigt problem som følge af en mangel på opfyldning af et universelt og iboende menneskeligt behov for lønarbejde - eller bliver det snarere et helbredsmæssigt problem som følge af konflikter og modsætninger mellem den socio-materielle organisering og kulturelle betydningstilskrivning af arbejdsløshed på den ene side og individets konkrete levevilkår og subjektive orienteringer på den anden?

Pointen er, at idéen om beskæftigelse som svaret på socialpolitikkens udfordringer ser ud til at bero på en ganske ureflekteret reducering af arbejde til lønarbejde og ydermere en problematisk homogenisering af lønarbejdet, som var alt lønarbejde skabt lige - og lige sundt. Man kan argumentere for, at der må skelnes mellem Mette Frederiksens grundlæggende holdning til, at det er bedst for (alle) voksne mennesker at gå på (al slags) arbejde - og så, at det kan være godt for (mange men ikke nødvendigvis alle) voksne mennesker at gå på (nogle former for) arbejde. Den sidste formulering og indstilling anerkender den reelle mulighed, at lønarbejde ikke er godt og sundt for alle. Det gør den første ikke. Denne ureflekterede holdning og mangel på forståelse for arbejdets mangfoldighed og pædagogiske potentialer vil jeg vurdere som havende lidt for godt albuerum inden for beskæftigelsessystemet $\mathrm{i}$ arbejdet med udsatte borgere: kommer man blot i lønnet beskæftigelse, så skal resten nu nok ordne sig mere eller mindre som følge af lønarbejdets vidunderlige mentale og fysiske sundhedseffekter. Men lønarbejdets sundhedseffekter synes nu at svinde eller såmænd helt ophøre i det tilfælde, at arbejdet opleves menings- og værdiløst i kombination med, at det måske endda udføres på trods af betydelige fysi- ske, kognitive eller psykiske udfordringer som det desværre ind i mellem er tilfældet for længerevarende arbejdsløse, når de af jobcentre kræves afprøvet gennem virksomhedspraktikker. Virksomhedspraktikker som jobcentrene er stærkt pressede på at skulle finde i massevis, nu hvor beskæftigelse bliver til det primære pædagogiske redskab for socialt udsatte borgere. I mit tidligere virke som arbejdspædagogisk konsulent inden for det kommunale beskæftigelsessystem, har jeg observeret, at det desværre ofte og af ren praktisk nødvendighed leder til indgåelse af lokale aftaler mellem jobcentre og større virksomheder, der lover at tage imod et vist antal borgere årligt. Presset medfører en konkret mangel på ressourcer i forhold til at kunne finde en virksomhedspraktik, der er passende, meningsfuld og hensigtsmæssig præcis i forhold til den enkelte borgers arbejdsmæssige deltagelsesmuligheder og -begrænsninger; eller 'skånehensyn' som det hedder på beskæftigelsessprog. Det er én ting, at der ser ud til at være mangel på ressourcer, hvad angår mulighederne for at finde passende virksomhedspraktikker til det enkelte individ - det er som sådan slemt nok i sig selv. Men derudover kan man spore en tendens til, at jobcentrenes jobkonsulenter enten er så overbebyrdede eller ikke er udstyret med den passende faglighed, at arbejdets pædagogiske og læringsmæssige potentiale ikke udfoldes noget nær tilstrækkeligt. Talrige borgere, som jeg i min stilling som arbejdspædagogisk konsulent har samarbejdet med over de seneste tre år, har oplevet, at de gennem deres jobcenterstyrede forløb er startet i en praktik for kun at blive bedt om en kortere opfølgning fra deres jobkonsulent hen mod vejs ende. Resten af tiden har de (og praktikværten) oplevet at være blevet ladt alene om projektet, og her viser det sig altså, at simulering af lønnet arbejde i form af praktikker ikke just klarer opgaven af sig selv. Såfremt arbejdet skulle være et (pæda- 
gogisk) middel i retning mod et bedre og mere værdigt menneskeliv, sådan som det er blevet formuleret både fra borgerligt såvel som fra socialdemokratisk hold, skulle der eksistere et professionelt, pædagogisk rum samt tid til i fællesskab at gribe og bearbejde de erfaringer, borgeren gør sig under, og sideløbende udenfor, virksomhedspraktikkerne. Ellers går arbejdets læringsmæssige potentiale som sagt tabt, og i værste tilfælde forværres borgerens situation. Eksempelvis som følge af stresspåvirkninger grundet for hårde eller uhensigtsmæssige arbejdsvilkår i praktikken, oplevelse af mangel på kontrol over egne livsbetingelser og håbløshed mv. Med Fjodor Dostojevskijs ord:

\begin{abstract}
"Jeg faldt engang på den tanke, at dersom man ville aldeles knuse og tilintetgøre et menneske, dersom man ville lade ham lide en straf så grusom, at selv den mest ryggesløse morder ville skaelve og roeddes for denne straf, så behøvede man blot at give hans arbejde karakteren af en fuldkommen meningsløshed og nyttesløshed" (Dostojevskij, 1972, s. 31)
\end{abstract}

\section{Det levende arbejde - for en levende beskæftigelsesindsats}

Indtil videre har jeg problematiseret beskæftigelsespolitikkens kolonisering af socialpolitikken ud fra det synspunkt, at det er sket uden en tilstrækkelig indholdsbestemmelse af det arbejde, der skulle kunne tænkes at hjælpe udsatte borgere hen imod bedre liv på trods af deres sammensatte udfordringer - sådan som det har været det politiske håb. Alligevel vil jeg fastholde, at udviklingen eller tanken ikke er håbløs. Men det vil kræve en vilje til at udvide arbejdsbegrebet og dets indhold, såfremt man skal gøre sig nogle forhåbninger om at kunne udnytte det pædagogiske og læringsmæssige potentiale. Det vil jeg komme nærmere ind på nu.
Det arbejde der bliver kritiseret som subjektivt meningsløst og ofte i beskæftigelsesindsatsen tager form af virksomhedspraktikker af forskellig længde kunne betegnes som det fremmedgjorte arbejde. Begrebet optræder såmænd i rigt omfang og har spillet en stor rolle som socialanalytisk koncept i kritisk teori - men den nærværende brug af det vil være afskåret fra de eksplicitte kapitalismekritiske og essentialistiske grundtoner, da det ikke er en vej, jeg vil gå ned ad i denne kronik. Det fremmedgjorte arbejde, sådan som jeg karakteriserer det i det kommende, er også indeholdt i Dostojevskijs citat fra tidligere. Jeg vil tilnærme mig det som den type arbejde, hvor subjektet ikke umiddelbart er i stand til at danne betydningsfuld forbindelse mellem arbejdsdeltagelsen og arbejdets indhold (i praktikken) samt egen (arbejds) livshistorie - altså den subjektive betydning arbejdet har haft for individet gennem livet. Oplevelsen af åbenlys mangel på relevans og evne til at skabe sammenhæng mellem egne livshistoriske erfaringer samt livsaspirationer og så ens konkrete deltagelse i beskæftigelsesforløb, er altså en faktor i tilblivelsen af det fremmedgjorte arbejde - en systemisk forstyrrelse, blokering eller begrænsning af individets subjektive tilegnelse eller erfaring af arbejdet (Jaeggi, 2014). Endvidere er der både et nutids- og fremtidsperspektiv: Det fremmedgjorte arbejde bliver til, når borgerens nutidige erfaring af den konkrete arbejdets indhold og form opleves ubehageligt eller upassende på det umiddelbare plan. Det kan være, at borgeren ikke oplever praktikværten som tilstrækkeligt informeret om borgerens situation og de særlige behov, der måtte være knyttet hertil. Eller for den sags skyld, at kollegaerne ikke er informeret, og at borgeren derfor af dem bliver kastet ud i arbejdsopgaver, han eller hun reelt set ikke oplever sig tilstrækkelig kompetent eller klar til at udføre. Det kunne også være, at arbejds- 
miljøet ikke er gennemtænkt på forhånd og tilpasset eksempelvis kognitive, sociale eller sanselige udfordringer, borgeren måtte have. Det kunne eksempelvis være, at en borger med langvarige følger efter hjernerystelse bliver sat i praktik i et supermarked, hvor der er en overflod af sociale, visuelle og auditive stimuli eller oplever borgeren at vedkommendes delvise arbejdsdeltagelse og indsats udgør en betydningsfuld og nyttig del af det konkrete arbejdets helhed? Man kan måske med lidt løselig brug af brugs- og bytteværdibegreberne formulere det således: opleves praktikdeltagelsen som havende en konkret og erfaringsbar brugsværdi for borgeren selv og/eller for arbejdsfællesskabet - eller opleves det blot som havende en gold bytteværdi i form af at være nødvendig for ret til den fortsatte offentlige ydelse og for måske efterfølgende at få nogle måneders fred fra systemets indgreb? Det handler altså her om den umiddelbare erfaring af meningen og hensigtsmæssigheden af arbejdet eller praktikken. Det er dog samtidig en pointe, at den umiddelbare erfaring og fortolkning samt bearbejdningen af denne vil være betinget af den enkelte borgers tidligere erfaringer og livshistorie. De umiddelbare erfaringer skal derfor ikke forstås som opstående i et vakuum. Foruden de fortidige og nutidige aspekter ved erfaringen af det fremmedgjorte arbejde, spiller fremtidsperspektivet, som allerede er berørt delvist i ovenstående, ligeledes en væsentlig rolle. Det gør det i den forstand, at erfaringen af eksempelvis virksomhedspraktikker som meningsfulde til en vis grad også er afhængig af, om borgerens praktikforløb vurderes som havende en reel betydning for eget videre liv, ens færden i beskæftigelsessystemet og som i overensstemmelse med egne idéer om det gode liv. Det vil sige, er der med praktikken håb om, at man kan opnå reel læring og forbedring af sine livsbetingelser samt udvidelse af arbejdsmæssige deltagelsesmuligheder? Eller i det mindste at praktikken fører til en afklaring af ens jobcentersag, sådan at man kan opleve chance for at komme videre $i$ livet og i den nærmeste fremtid genvinde kontrol over eget fremtidige livsforløb? Det fremmedgjorte arbejde bliver således til som følge af en dialektik mellem fortidige, nutidige og fremtidige erfaringshorisonter - men også som et resultat af arbejdet blot for arbejdets skyld, sådan som Max Weber kritiserer arbejdets formtagen i en kapitalistisk tidsånd (1995). Og det siger næsten sig selv, at det fremmedgjorte arbejde - som opstillet her - kun i ringe grad vil kunne fungere som et middel til løsning af socialpolitikkens opgaver og forbedring af socialt udsattes livsvilkår. Ikke desto mindre udgør det fremmedgjorte arbejde størstedelen af indholdet i beskæftigelsesindsatser. Og det er den primære årsag til, at det potentiale, som eks. Mette Frederiksen, Socialdemokratiet og andre har set i beskæftigelse som socialfagligt redskab, går tabt.

Arbejdets potentiale som pædagogisk middel er den daværende regeringen dog ikke alene om at have formuleret. Den type arbejde, der kan siges at have pædagogisk og læringsmæssigt potentiale kan - med lån fra eksempelvis Oskar Negt - betegnes som det 'levende arbejde' (Negt, 1985). Det levende arbejde i en beskæftigelsesindsatssammenhæng står på flere måder i et skarpt modsætningsforhold til det fremmedgjorte arbejde, og ville i en beskæftigelsessystemisk kontekst kunne karakteriseres ved en oplevelse af subjektiv relevans og mening ift. det enkelte menneskes unikke livshistorie, tidligere arbejdsliv og 'rettethed'. Det vil sige, at det på det umiddelbare erfaringsplan opleves som lærerigt, givtigt, passende og rart samt at det i betydelig grad vurderes af borgeren som stemmende overens med vedkommendes ønsker og tanker om fremtiden.

Som nævnt mener Pernille Rosenkrantz-Theil, at førtidspensionsreformen 
er blevet forvaltningsmæssigt læst af kommunernes jobcentre, som fanden læser biblen. Men helt galt på den, ville man nok ikke være, såfremt man påstod, at det også er arbejdet som praksis, der er blevet udsat for sådan en læsning: Altså, at arbejde som svaret på socialpolitikkens problematikker er læst udelukkende som udifferentieret lønnet erhvervsbeskæftigelse, som fremmedgjort arbejde - uden forsøg på at indholdsbestemme eller begrebsliggøre arbejdet samt dets pædagogiske og læringsmæssige dimensioner ift. beskæftigelsesindsatser for socialt udsatte borgere yderligere. Det levende arbejde er sjældent en del af læsningen, og derfor må der tilskyndes til bredere og mere nuancerede konceptualiseringer af arbejdet. I den forbindelse er det værd at bemærke, at arbejdsbegrebet jo bestemt ikke er komplet fremmed for den pædagogiske teori og praksis, om end man kunne komme til at tro det, sådan som beskæftigelsesfeltet i dag fremstår relativt renset for voksenpædagogiske tanker og arbejdsteoretiske idéer.

\section{En (arbejds) pædagogik for beskæftigelsesfeltet?}

Det skærende ved den aktuelle situation er som sagt, at man i den danske beskæftigelsesindsats skal lede længe efter pædagogisk fantasi og kreativitet i de metodiske tilgange såvel som refleksioner over arbejdets subjektive betydning for mennesket. Dette er på trods af, at man har med socialt udsatte og arbejdsløse borgere at gøre, for hvem det netop er et relativt gennemgående karakteristika, at de må navigere i voldsomt komplekse livsvilkår og deltagelsesbetingelser samt håndtere svært sammensatte problemstillinger i relation til sygdom, materielt levegrundlag, sociale forhold, fysiske gener, destabiliseret hverdagsliv eller psykiske lidelser. I lyset heraf vil jeg opfordre til, at man fra beskæftigel- sesforskningens og -praksissens side fremadrettet gør sig besværet med at forsøge at inddrage viden fra (voksen)pædagogisk forskning såvel som arbejdslivsforskningen. Målet må være at kvalificere forståelsen af præmisserne for voksnes læreprocesser og deltagelse i beskæftigelsesfremmende forløb, arbejdets pædagogiske aspekter såvel som arbejdets potentielle betydninger for mennesket i vores senkapitalistiske samfund. Og her kan man som sådan pege kikkerten i mange retninger - eksempelvis i retning af den historiske arbejdsskolebevægelse (Freinet, 1980; Håkonsson, 1982; Hermansen, 1985; Husen, 1978), hos hvem det levende arbejde blev formuleret og praktiseret som pædagogisk og emancipatorisk princip i opdragelsen og undervisningen af børn. Noget der kunne have tilsvarende relevans for voksenpædagogiske kontekster, hvis der arbejdes på en praktisk oversættelse af disse idéer. Man kan skue mod Negts begreb om sociologisk fantasi eller Paolo Freires frigørende pædagogik med henblik på at udvikle et modsvar til den øgede individualisering af den arbejdsløses udfordringer og dermed også tendens til en destruktiv inderliggørelse af spørgsmål om skyld og årsager til arbejdsløshed (Freire, 1997; Negt, 1975). Man kunne utvivlsomt også fremfinde relevante indsigter fra forskning i arbejdsløshed og subjektivitet (Olesen, Weber, Larsen \& Nielsen, 1994) eller den voksenpædagogiske livshistorieforskning i forhold til at forstå, hvordan arbejdsløse og socialt udsattes erfaring af deltagelse i beskæftigelsesforløb er betinget af og indgår i en aktiv og kontinuerlig (re)fortolkning af egen individuel livshistorie - en proces der i øvrigt er stærkt rammesat af de aktuelle samfundsmæssige strukturer og den konkrete organisering af eksempelvis jobcentrene (ex. Olesen 2000, 2010; Weber, K. 1999)

Grundet kronikkens format og min øvrige disponering kan jeg beklageligvis ikke gå 
længere ind i ovenstående, hvilket vil være en opgave for en anden dag og anden tekst. Derfor kommer det mest af alt til at fremstå som en eksemplificering af, at der er muligheder. Og at mulighederne er mange. Heldigvis. For skulle det hænde, at beskæftigelsespolitikkens absorbering af socialpolitikken er irreversibel, så må beskæftigelsesfeltet unægteligt og i højere grad skue i pædagogikkens retning, hvis vi skal gøre os noget håb om at kunne bedrive en anstændig, meningsfuld og fremmedgørelsesreducerende indsats for socialt udsatte mennesker. Det er ikke sikkert, at der behøves ske en nostalgisk tilbagerulning af den nuværende udvikling i form af en tilbagevenden til en komplet afkobling af social- og beskæftigelsespolitik samt disses praksisfelter. Der kan være potentiale i arbejdet - ja endda i lønarbejdet - som pædagogisk rum for læring og udvikling, også for socialt udsatte borgere. Men såfremt dette potentiale skal udfoldes, må der nødvendigvis skabes meget bedre rammer for at udøve arbejdet som pædagogisk praksis og undgå den fremmedgørende effekt. Her er beskæftigelsesfeltet pt. dårligt stillet grundet alt for højt antal borgere per sagsbehandler, ligesom jobkonsulenter er nødt til at centrere al deres energi om blot at finde tilstrækkeligt mange praktikpladser til den store mængde af mennesker, der kommer gennem beskæftigelsessystemet. Ligeledes vil det højst sandsynligt være nødvendigt med en overordnet ledelsesmæssig vilje til at indsætte arbejdet som et reelt pædagogisk rum for udvikling og læring. En kulturændring om man vil. Måske med indsættelse af pædagogiske og socialfaglige mellemledere som supplement til den øverste jobcenterledelse, hvis fagligheder aktuelt ser ud til at være funderet $\mathrm{i}$ forvaltning, jura eller erhvervsøkonomi. Politisk bør der skrues ned for styringen af jobcentrene som private virksomheder med alt for stramme budgetter og økono- miske incitamentstrukturer, hvorigennem jobcenterledelsen i stor stil måles og belønnes ud fra evne til budgetoverholdelse frem for kvaliteten af den sociale og pædagogiske faglighed. I en ideel og skøn verden ville argumentet for sådanne ændringer blot kunne legitimeres og begrundes ud fra en almen etisk forpligtelse ift. anstændig og meningsfuld behandling af ens medmennesker - og et samfunds syge, udsatte samt arbejdsløse. Beklageligvis må man dog nok konstatere, at der i den reelle verden skal mere samfundsøkonomiske, instrumentelle argumenter til. I den forbindelse vil jeg således vove påstanden, at forbedringer af det levende arbejdes pædagogiske rolle og mulighedsbetingelser i beskæftigelsesindsatsen vil medføre en reel sandsynlighed for, at flere arbejdsløse borgere - som afledt effekt af 'arbejdet som middel' - kommer i den ene eller anden form for lønnet erhvervsarbejde, end hvis man fortsætter som hidtil med at bære klapper for de voksen- og arbejdspædagogiske øjne og med at reducere kompleksiteten af socialt udsattes livsvilkår.

\section{RefERENCER}

Benjaminsen, L. (2017). Hjemløshed i Danmark 2017. National kortloegning. VIVE - Det Nationale Forskningscenter for Velfærd.

Bredgaard, T., Jørgensen, H., Madsen, P. K. \& Rasmussen, S. (2011). Dansk arbejdsmarkedspolitik. Dansk arbejdsmarkedspolitik. København K.: Jurist- og Økonomforbundets Forlag.

Caspersen, S. (2018). Siden 2010 er indkomsten stagneret for de 40 pct. fattigste: Arbejderbevægelsens Erhvervsråd.

Dostojevskij, F. (1972). Optegnelser fra Det Døde Hus. Aalborg: Stig Vendelkærs Forlag.

Eeg, A. \& Jensen, W. (2018). Arbejdsløsheden juni 2018 - Arbejde, indkomst og formue: Danmarks Statistik.

Frederiksen, M. (2013). Mette Frederiksens tale til Socialchefforeningen. Lokaliseret fra https:// 
www.denoffentlige.dk/mette-frederiksens-tale-til-socialchefforeningen

Freinet, C. (1980). Arbejde som poedagogisk princip - Den frie tekst. København: Reitzels Forlag.

Freire, P. (1997). De undertryktes poedagogik: Christian Ejlers.

Goli, M. (2016). Beskæftigelsespolitik mellem struktur og konjunktur. I M. Goli \& L. Hansen (Red.), Beskoeftigelsespolitik og socialt arbejde (2. udg.): Hans Reitzels Forlag.

Goodman, N. (2015). The Impact of Employment on the Health Status and Health Care Costs of Working-age People with Disabilities. LEAD Center Policy Brief.

Håkonsson, E. (1982). Arbejdsbegrebet diskuteret ud fra Freinet-pædagogikken. Dansk Padagogisk Tidsskrift, 30 (5), 194-206.

Hermansen, M. (1985). Arbejd for livet - om undervisning og fremtid. København: Nordisk Forlag.

Husen, M. (1978). Arbejdsbegrebet i den poedagogiske filosofi - Georg Kerschensteiners dannelsesteori. Odense: Odense Universitetsforlag.

Jaeggi, R. (2014). Alienation. New York Chichester, West Sussex: Columbia University Press.

Jahoda, M. (1982). Employment and Unemployment - A Social-Psychological Analysis. New York: The Press Syndicate of the University of Cambridge.

Juul, J. S. (2018). Rekordmange børn er under fattigdomsgroensen. Arbejderbevægelsens Erhvervsråd.

Negt, O. (1975). Sociologisk fantasi og eksemplarisk loering: Til teori og praksis i arbejderuddannelsen. Roskilde: RUC Boghandel \& Forlag.
Negt, O. (1985). Det levende arbejde - den stjålne tid. København: Politisk revy.

Olesen, H. S. (2000). Experience and Life History. Roskilde: Adult Education Research Group, Roskilde University.

Olesen, H. S. (2010). Modernization processes and the changing function of adult learning. International Encyclopedia of Education, 217-222. doi:10.1016/B978-0-08-0448947.00043-9.

Olesen, H. S., Weber, K., Larsen, K. \& Nielsen, B. S. (1994). "Arbejde og subjektivitet" i dag - temaets status og aktualitet. I: Arbejde og subjektivitet: En antologi om arbejde, køn og erfaring (s. 9-33).

Rosholm, M., Sørensen, K. \& Skipper, L. (2017). BIP indikatorer og jobsandsynlighed. Væksthusets Forskningscenter.

Ross, C. E. \& Mirowsky, J. (1995). Does employment affect health? Journal of Health and Social Behavior, 36 (3), 230-243. doi:10.2307/2137340.

Turner, J. B. \& Turner, R. J. (2004). Physical Disability, Unemployment, and Mental Health. Rehabilitation Psychology, 49 (3), 241-249. doi:10.1037/0090-5550.49.3.241.

Weber, K. (1999). Concepts of Life History and Biography: Understanding Lifelong Learning? Roskilde: Adult Education Research Group, Roskilde University.

Weber, M. (1995). Den protestantiske etik og kapitalismens ånd: Lindhardt \& Ringhof.

\section{Mikkel B. B. Morgen,}

Ph.d.-studerende, Institut for Mennesker og Teknologi, Roskilde Universitet og Center for Specialundervisning Slagelse e-mail:mbbh@ruc.dk 